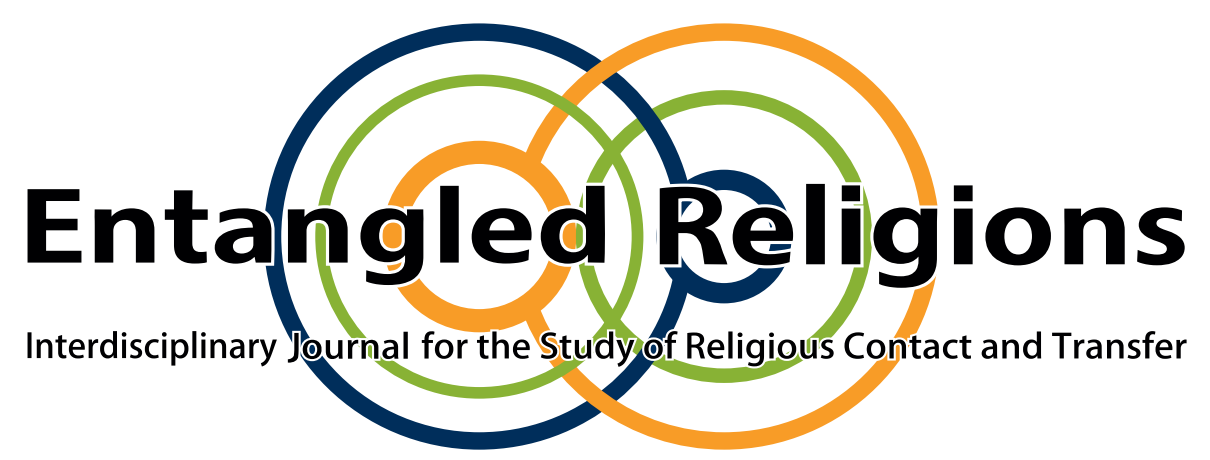

\title{
Shared Shrines and the Discourse of Clashing Civilisations
}

\section{GLENN BOWMAN}

Emeritus Professor of Socio-Historical Anthropology, School of Politics and International Relations, University of Kent, England

This contribution to Entangled Religions is published under the Creative Commons Attribution 4.0 International Public License (CC BY 4.0 International). The license can be accessed at https://creativecommons.org/licenses/by/4.0/legalcode.

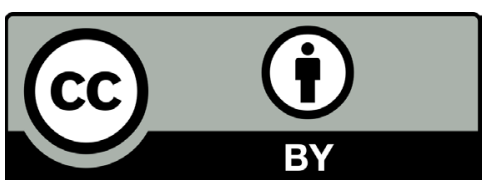

Entangled Religions 9 (2019) http://doi.org/10.13154/er.v9.2019.108-138

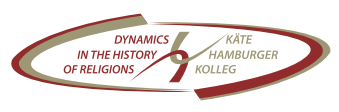




\title{
Shared Shrines and the Discourse of Clashing Civilisations
}

\author{
GLENN BOWMAN
}

University of Kent

\begin{abstract}
Since I began, in the early 1980s, to research Muslim-Christian cohabitation of religious sites, I have been convinced of the political importance of making practices of intercommunal 'sharing' ethnographically visible. Thirty-five years of that work, spread across the Eastern Mediterranean (Israel/ Palestine, Yugoslavia and its successor states, and both sides of the Cyprus divide), have not only revealed contemporary and historical choreographies of cohabitation but also their disintegration and the forces which bring it about. While I was carrying out this research, an accelerating resurgence of ethnic, religious and nationalistic politics was taking place not only throughout the areas I was studying but also in the global arena. This 'identitarian' politics, its philosophical grounding, and its shaping of academic and popular thought and practice is the focus of the first half of this paper; in the second part I look theoretically and empirically into examples of sharing and its refusal so as to show not only how cohabitation with alterity works but also to make visible the processes which sabotage it.
\end{abstract}

KEY WORDS Intercommunal relations; shrines; identity; space; place; clash

of civilisations; discourse; commensality; antagonism

\section{Introduction ${ }^{1}$}

Over the past couple of years, events have taken place that foreground the importance of the material addressed in this article. The referendum on the U.K.'s membership in the European Union, called in order to protect David Cameron's prime ministership from the right wing of the Tory party, gave rise to a heated debate about the place of 'foreigners' in Great Britain, culminating in a contentious decision to avoid the immigration of others, regardless of what such avoidance might cost. Across the Atlantic, the vitriolic rhetoric of Donald Trump and his fellow travellers, again focussing on the need to protect an ill-defined 'us' from a threatening 'them', gave the presidency of the most powerful state in the world to a man promising to exclude Muslims, expel immigrants, and build walls against territorial neighbours. In France, Holland, Hungary, and elsewhere in Europe a populist nationalism has burgeoned, threatening to erode, if

1 A section of this paper is drawn from an earlier text, Bowman 2016, published by Berghahn Books. 
not eradicate, the progressive gains that the West, and with it much of the world, has enjoyed since the end of the Second World War.

\section{Constructing Others}

One of the more troubling aspects of these events is that the 'Other' against which people turn is not simply that of a territorial outside deemed antagonistic but is as well made up of people and communities living in contiguity with those who have come to see them as threatening and unwelcome. Trump's proposed deportation orders refer to 'illicit' residents who, in many cases, have been born and raised to adulthood in the USA, while in the UK, as in France, Holland, and elsewhere in contemporary Europe, people who have been long integrated into those countries and their local communities are targeted by politicians and governmental agencies that question, and often delegitimate, their rights to be there. Undeniably, there are people who repeat and amplify the antagonistic messages accompanying and promoting these events. Some of these have always been around, nursing their antipathies in silence or manifesting them under the cover of media darkness, but, as recent surges of racialist and sectarian attacks have shown, the normalisation of discourses of intolerance and hatred gives legitimacy to their rage and encourages them to emerge from the shadows to call on others to take up their crusade. As those discourses proliferate and are subtly or not so subtly legitimated by governmental, academic, and media dissemination, calls to neighbour hatred come to seem increasingly commonsensical and anything but marginal.

Outbreaks of intolerance and hatred are not simple expressions of primordial antagonisms, despite what Robert Kaplan (1993) has suggested with reference to the wars in Yugoslavia. In the case of most if not all of the countries mentioned above, contemporary nationalisms are recent constructions produced by discursively amalgamating a number of different communities (and excluding others). However, even where the sectarian and religious identifications that morph into nationalist identities are historically well established-as may arguably have been the case in now Former Yugoslavia-it is quite evident that those histories are marked by long-term commensality with ethnic or sectarian Others, operating with a range of intensities (Baskar 2012; Henig 2012; Sorabji 2008).

Commensality can nonetheless, in certain contexts, disintegrate into intercommunal antagonism. ${ }^{2}$ What is vital to consider in investigating such outbreaks is what it is 
that disrupts everyday interaction and brings about intercommunal antipathies and violence. I have argued with reference to Yugoslavia and Israel/Palestine (Bowman 2003) that such eruptions are discursively prepared and, once effected, maintained in a feedback loop through which images of the dangerous Other are amplified and circulated by narratives rendering those images verisimilitudinous. Certainly, gruesome reports of ISIS violence as well as images of waves of Islamic refugees crashing against the borders of the nation state (even if, in the case of the most powerful picture in the bank of UKIP propaganda, those borders belonged to Slovenia and Croatia rather than the U.K.) made visceral the threat many had come to feel in the face of what they were told to see as encroaching Islam. These images, moreover, served for many simply to confirm pre-existing opinions about the danger not only of Islam but of cultural alterity full stop (blacks, Mexicans, Eastern Europeans, etc.). These opinions, I contend, were fomented by two decades or more of intellectual debate and media dissemination of identitarian arguments about the impossibility of living with 'others'.

\section{The Clash of Civilisations}

The extensibility of the image of the threatening Other testifies to a paradigm shift which, for illustrative reasons, I will trace back to the impact of Samuel Huntington's hypothesis of a 'clash of civilisations' (Huntington 1993, 1996), although it must be acknowledged not only that Huntington's argument was not original, having precursors in the work of orientalists such as Bernard Lewis (Lewis 1990), but also that other forms of identitarianism were simultaneously gaining in popularity. ${ }^{3}$ Huntington's thesis is too well known to need reiterating at length, but it can be summed up in a selection of quotes from his original Foreign Affairs article:

lepo gore) 1996, director Srdan Dragojevic, a fiction film produced in Belgrade soon after the end of the War of Yugoslav Seccession.

3 Consider here Alain Badiou's argument that the advent of the 1980s marks the end of a short century of a multitude of radical collective wills to transformation that is followed by the decades in which he writes (and in which we continue to live) marked by "the dominance of an artificial individualism" (Badiou 2007, 98). Badiou writes that "if you think the world can and must change absolutely; that there is neither a nature of things to be respected nor pre-formed subjects to be maintained, you thereby admit that the individual may be sacrificable....The individual is not independently endowed with any intrinsic nature that would deserve our striving to perpetuate it" (ibid., 99). The contemporary alternative sanctifies the will of the individual encased in its identity and thus-despite the individuality of its apparent narcissism-locks the individual into the collectivity of cultural being. This is an ontological conservatism: "there is a 'nature of things' and violence must not be done to it" (ibid.). 
The fault lines between civilizations will be the battle lines of the future... differences among civilizations are not only real; they are basic. Civilizations are differentiated from each other by history, language, culture, tradition and, most important, religion. The people of different civilizations have different views on the relations between God and man, the individual and the group, the citizen and the state, parents and children, husband and wife, as well as differing views of the relative importance of rights and responsibilities, liberty and authority, equality and hierarchy. These differences are the product of centuries. They will not soon disappear. They are far more fundamental than differences among political ideologies and political regimes. (Huntington 1993, 23 and 25)

Huntington's argument for conflictual civilizational difference is primarily territorialist, positing spatial differentiation between 'civilisations' entailing “bloody borders" (1993, 35) as well as "fault lines between civilizations" (1993, 29ff). This not only makes for conceptual problems in areas where 'civilisations' are mixed without conspicuous bloodshed but also in understanding displacements, diasporas, and migrations that 'mix' civilisations in the same territories. Furthermore, the clash of civilisations argument is simultaneously profoundly essentialist and deeply 'groupist' (see Brubaker 2002 , 164ff). Referring to the core example he poses of inter-civilisational antagonism, Huntington writes that "conflict along the fault line between Western and Islamic civilizations has been going on for 1,300 years" (1993, 31). This temporal continuum from the defeat of Justinian II at Sebastopolis (692 C.E.) to the emergence of political Islam in Algeria and Central Asia (Kazakhstan, Kyrgyzstan, Tajikistan, Turkmenistan, and Uzbekistan) in the early $1990 \mathrm{~s}^{4}$ erases social and political processes (and with them history per se) while at the same time downplaying diversity and antagonism within 'civilisational groups'.

'Groupism', which Brubaker defines as a "tendency to take bounded groups as fundamental units of analysis (and basic constituents of the social world)" (2004, 2), results, in Huntington's analysis, in constituting civilisational 'communities' as transhistorical entities melding together all those who identify with what we can finally only see as a name. Hence a civilisation is

the highest cultural grouping of people and the broadest level of cultural identity people have short of that which distinguishes humans from other species. It is defined both by common objective elements, such as language, history, religion,

4 See Robin Wright's "Islam, Democracy and the West”, published a year earlier than Huntington's article in the same journal, for a far more nuanced and less confrontational take on Islam and the West at that historical moment (Wright 1992). 
customs, institutions, and by the subjective self-identification of people. People have levels of identity: a resident of Rome may define himself with varying degrees of intensity as a Roman, an Italian, a Catholic, a Christian, a European, a Westerner. The civilization to which he belongs is the broadest level of identification with which he intensely identifies. (Huntington 1993, 24)

For Huntington that 'intense identification' is at the core of civilisational identity, but investigation shows that the object of such identification (say 'Islam') will, while retaining its nominal identity, vary its meaning depending on which community (or even individual) is identifying with it in what historical period. Huntington's Islam, for instance, effaces the distinctions between and within communities (not to mention individuals) of Shi'a and Sunni Muslims while simultaneously discounting differences between Salafists, the many Sufi orders, and diverse other forms of Islam (cf. Gilsenan, 1982). Here the object of identification — the name 'Islam' - is what Kripke, Peirce, and others have termed a 'rigid designator'. Peirce describes its construction in personal terms: "I believe in mooring our words by certain applications and letting them change their meaning as our conceptions of the things to which we have applied them progress" (Charles S. Peirce, A Treatise on Metaphysics, 1861-1862, quoted in Short 2007, 264). ${ }^{5}$ Peirce's idea that nominatives might retain their form while shifting their meanings as changing experience so necessitates can easily be extended beyond personal histories to those of communities scattered in their diversity and developing over time while retaining nominal allegiance to a term of identification, such as Islam. As, obviously, that locus of identification mutates, so, too, do the antagonisms posited as fixed by identitarian essentialists such as Huntington. One Muslim, living in the same community as another, may feel an abiding hatred for all things 'Western' based on her interpretation of 'Islam', while a neighbour, similarly attesting full identification with Islam, might find Western lifestyles and Western neighbours attractive and compatible. ${ }^{6}$

5 What Peirce describes is an "initial baptism" (Kripke 1980, 96-97 and passim) whereby a word is linked to a reference prior to being passed on to different contexts along a chain of communication, in the course of which the reference shifts yet is still indicated by the same word. Žižek, parsing Kripke, writes that "it is the word which, as a word, on the level of the signifier itself, unifies a given field, constitutes its identity. It is, so to speak, the word to which 'things' themselves refer to recognize themselves in their unity.... It is not the real object which guarantees as the point of reference the unity and identity of a certain ideological experience-on the contrary it is the reference to a 'pure' signifier which gives unity and identity to our experience of historical reality itself" (Žižek 1989, 95-96 and 97, see also Kripke 1980 and Vološinov [1929] 1973, 79-80).

6 A dramatic example of this is the BBC2 series Muslims Like Us (directed by Fatima Salaria), screened on 5 and 12 January 2017. 
Such contemporary responses will differ substantially from earlier manifestations of Islamic belief and practice.

\section{Promoting Identitarianism}

Despite Huntington's model's conceptual weaknesses, it has proved highly influential in shaping both political and popular thinking about Islam in particular and alterity in general: Richard Bonney $(2008,35)$ asserts that "no thesis has had a comparable influence on Western, especially American, strategic thinking since the end of the cold war." It has certainly become an academic and popular touchstone for discussions on cultural identities and antagonisms. From what does such influence devolve?

Jane Mayer, an investigative journalist associated with The New Yorker, published Dark Money in 2016 (Mayer 2016a). Here, she argues that John M. Olin, through his Olin Foundation and with the cooperation of a number of other private foundations, "funded the creation of a conservative counter-intelligentsia...to reorient the slant of American higher education to the right" (Mayer 2016a, 94 and 93, see also Spring 2010, 121150). The Olin Foundation funded professors at influential universities throughout the country, among them Milton Friedman (Free to Choose, 1980), Charles Murray (Losing Ground: American Social Policy 1950-1980, 1984; and, with Richard Herrnstein, The Bell Curve: Intelligence and Class Structure in American Life, 1994), Allan Bloom (The Closing of the American Mind, 1987), Dinesh D'Souza (Illiberal Education, 1991), and John R. Lott Jr. (More Guns, Less Crime, 1998). The resultant (often disputed) scholarship was not only disseminated via academic channels but also massively amplified by the attention given to its media and political promotion. Thomas Medvetz, in his Think Tanks in America, examines the extensive promotional efforts invested in Charles Murray's Losing Ground to exemplify the ways that right wing institutes promote the work they have funded (Medvetz 2012, 1-5). Murray, commenting on the way his book went from being a radical outlier assault on welfare to being the "compulsory point of reference" (quoted in ibid., 5) in political discussions, noted that "it took ten years for Losing Ground to go from being controversial to conventional wisdom. And by the way there is very little in Losing Ground right now that's not conventional wisdom" (quoted in ibid.). ${ }^{7}$

7 Lawrence Mone, director of the Olin-funded Manhattan Institute for Policy Research, commented that Losing Ground "captured the strategic audience,...journalists who could reframe the terms of the debate. Charles targeted this audience and his book hit the bull's eye.... Slowly but surely over the course of the next ten years, it totally flipped the conventional wisdom on welfare. And that flip led ultimately to the welfare reform bill of 1996" (Interview, 14 June 2004 in Medvetz 2012, 241). 
In 2005, Lawrence Mone told Lizzy Ratner of The Observer that "the Olin Foundation was one of the two or three major conservative foundations that laid the intellectual infrastructure of what we see today" (Ratner 2005, unpaginated). One of the primary beneficiaries of the Olin Foundation's programme of "taking the liberal out of liberal arts education" (Mayer 2016, 104) was Samuel Huntington, who received 8.4 million dollars from the Foundation to establish and run his "hawkish" (Mayer 2016b, unpaginated). John M. Olin Institute for Strategic Studies at Harvard that sponsored 88 fellows between 1990 and 2001, 56 of whom took up professional academic careers at prestigious and Ivy League universities while others "became public figures in government, think tanks, and the media" (Mayer 2016b, unpaginated). ${ }^{8}$ Huntington and the Olin Foundation generated what I would argue was a significant shift in how identities and communities were conceptualised in both popular and academic discourses, and that influence spread far beyond the direct reach of both funding and patronage.

\section{Civilisations Clashing on Shared Religious Space}

The 'clash of civilisations' discourse promoted by Huntington and the Olin Foundation impacted powerfully_directly and indirectly_on scholarship, particularly in the United States. One of the significant sites of this impact was the debate on the 'sharing' of religious space. Ron Hassner argues in War on Sacred Grounds (2009) as well as in "The Pessimist's Guide to Religious Coexistence" (2010) that "sacred places cannot be shared" (Hassner 2009, 3):

The very same motivations that lead religious groups to attribute importance to sacred sites also lead these groups into conflict with religious rivals at these sites.... [T] he key to resolving religious conflict at sacred sites lies not in managing tensions between rival groups but in separating those groups from one another. (Hassner 2010, 146-147)

Hassner claims to find "the optimistic attitude that characterizes current research on inter-religious strife...nothing short of baffling" (ibid., 146) but writes it off as "part of a larger backlash against the pessimistic stance that has dominated the study of religion and politics since the publication of Samuel Huntington's Clash of Civilizations" (ibid.). Intriguingly, Hassner was, in 2003 and 2004, a Harvard post-doctoral fellow at 
Huntington's Olin Institute for Strategic Studies. ${ }^{9}$ His arguments for the centrality of religious identity in both the sharing of place and mobilisation for war (see his 2016 Religion on the Battlefield, Cornell) are profoundly civilisational.

Robert Hayden diverges significantly from the position put forward by Hassner, arguing that while for Hassner centrality refers to a site's "space in the spiritual landscape' of the religious community concerned" (Hayden 2016, 81) for him a holy place's "centrality refers to [its] location within a settlement or perhaps proximity to locations of important economic or political activity" (ibid., 720). What is signal for Hayden is the 'perceptibility' of the markers of another's presence in the holy place; a relatively low profile does not pose a threat to the community which holds the site, and the presence can be tolerated whilst a more eminent presence threatens and demands expulsion. Antagonism for Hayden depends on a notable threat to hegemony rather than one to sanctity; violence is "likely only when dominance is under contention and must be either acquired or (re)inforced" (Hayden 2015, 70).

Hayden has been critical of the clash of civilisations model, arguing that it "exemplif[ies] the 'cultural fundamentalism' that seems to be replacing classical racism as a rhetoric of exclusion" (Hayden 2000, 118 n3). Furthermore, the funding for his work on shared shrines has come not from Olin Foundation or other right-wing think tanks but from the National Science Foundation and the Wenner-Gren Foundation. ${ }^{10}$ Nonetheless, significant aspects of identitarian argumentation are present in his readings of intercommunal interactions around holy places, and these, I feel, have shaped his interpretations of shrine contestation. The association depends less on the 'civilisational' matter central to the Huntingtonian approach than in the groupism Brubaker has shown to be an essential element of identitarian arguments. Contesting my point that "religious sites and practices [are] maintained by and closely articulated with local populations [and]...such local sites can...be seen to reflect and amplify images of the consociality of the communities that surround, or had surrounded, them" (Bowman 2012c, 5), Hayden and his colleagues argue that

analyzing specific sites as if they were at least semi-isolated from larger religious, social, and political networks is inherently misleading. No matter how syncretic a site may seem at some moment, the people going there...are still connected to larger, non-local religious communities and their associated identities, and may

See his CV at http://polisci.berkeley.edu/people/person/ron-hassner (last accessed 2 February 2019).

10 Reputable institutions that, despite their probity, are vulnerable to influence from the encompassing intellectual milieu through peer refereeing and other determinants of selection. 
draw on these wider connections. In fact, much of our work is oriented towards analyzing how and when such extra-local ties are invoked. (Hayden et. al. 2016, 42)

Neither I nor others criticised by Hayden as naïve advocates of intercommunal sharing have denied that contests may come up between representatives of the varied groups 'sharing' shrines and that, in these contests, advocates of either group's hegemonic claims are likely to call on the support of co-religionists in the wider context. We have, however, made it clear that the groups sharing sites are not themselves unitary and that members sharing nominal allegiance are themselves very likely to dispute amongst themselves whether local ties with neighbours should be maintained or whether outside powers should be drawn in to reject them. The issue of who invokes extra-local ties and how that invocation is received seems a salient part of ethnographic description and raises the very central question of the relative autonomy of neighbourhoods and the associations they generate. This 'interference' is one salient way in which local (or 'micro' level) events are impacted by developments and discourses on the 'macro' level of national and global politics or institutional debates.

The antagonistic tolerance argument seems, however, to ignore such 'minutiae,' asserting that when dominance is seen to be challenged, the 'community' mobilises as a unitary entity: "religion may be the key identifying factor associated with a community and thus accepted as defining that group as opposed to others" (Hayden 2015, 70). Regardless of whether the members of a community engaging in intercommunal sharing choose, against the wider context, to continue to identify themselves with the diversity of their community (see Bigelow 2010), whether, as in the examples developed by Hayden and his colleagues in their works $(2002,2015,2016)$, they group as unitary communities to struggle against their neighbours for ownership of the sites, or whether, as in the case studied by Rohan Bastin (2012), religious authorities intervene to expunge signs of sharing despite the resistance of the mixed communities, what is important to discern, describe, and analyse is the politics of antagonism or accommodation. An identitarian approach which takes communal identity as a given, waiting latently to be 'switched on' by a change in the balance of power, prevents examination of the real play of politics in the same way that, in the clash of civilisations approach, the diversity of communities and their historical interactions within a 'civilisation' are rendered insignificant. 


\section{Choreographies of Cohabitation}

Investigations of cohabitation of shrines that are not based on identitarian models tend, for the most part, to be anthropological and/or historical and to be empirically based around case studies. ${ }^{11}$ To date a model has not emerged from this work, but that is perhaps for the better insofar as one of the chief findings of this research is that identity cannot be approached as fixed or groupist. These studies have demonstrated that peaceful intercommunal cohabitation around sacred sites exists, or has existed, although none have asserted that the willingness to share with others is an essential, necessarily durable, human characteristic. However, insofar as the focus of these studies has, in most of these cases, been limited to moments or periods of intercommunal interactions in and around the sites themselves, they might be seen, in their concern with amenable sharing, as being similar in their supposed essentialism to those that argue for an inbuilt competitive antagonism.

Hayden, for instance, criticises "inherently static and essentialist forms of analysis" (Hayden 2016, 84) that focus "on a particular combination of circumstances at a particular moment in time" (ibid., 83) as being, in effect, "structural-functional...and unable to handle social change" (ibid.). He faults the critics of his AT (antagonistic tolerance) model for failing to see that sacred sites are "inherently linked to social processes that are larger than the purely local" (ibid., 84) and asserts that

ethnography alone is inadequate to explain the relations between local groups even at the time when observations were made, unless the events analysed are contextualized in a trajectory of interactions between the religious communities concerned-communities not only at the local level but more widely as well. (ibid., 84-85)

11 For a partial listing in English of the anthropological material see Albera and Couroucli 2012; Barkan and Barkey 2014; Bigelow 2003, 2010, and 2012; Bowman 1993, 2012a, 2012b, 2012c, 2013a and 2013b; Cormack 2013; Couroucli 2009 and 2010; Driessen 2012; Koneska 2013; Lubańska 2013 and 2015; and Valtchinova 2012 and for the historical Barkey 2008: 109-153; Cuffel 2003, Fowden 1999 and 2002; and Meri 1999 and 2002. Also Lieux Saints Partagés (Albera, Penicaud and Marquette 2015), the catalogue of an exhibition on shared sites hosted by the Marseille's Mucem (Musée des civilisations de l'Europe et de la Méditerranée) and http://sharedsacredsites.net/sharedsacredsites. net, "a collaborative project that seeks to develop a rubric for the description, classification, analysis, and publication of work relating to spaces and locations used by multiple, disparate communities for religious purposes" (no pagination). Hassner and Hayden do, of course, mobilise specific site studies drawn from both ethnographic observation and historical research, but these serve to exemplify the tenets of general models rather than as starting points for processes of inductive reasoning. 
Although sophisticated work bringing together ethnographic and historical research, such as that of Anna Bigelow, ${ }^{12}$ certainly cannot be charged with either not handling social change or failing to link up with processes larger than the local, it is true that emphasis on the 'local' and the 'ethnographic present' within the specific context of sacred places enables the advocates of the AT position to charge the 'sharers' with a degree of political naivety. That focus, however, and the attention to the details of interpersonal and intercommunal interaction it enables, serves to highlight the dynamics of relations in and around a site, to interrogate the changing discourses operative in those situations, and to investigate what enables and what disrupts 'mixing' (cf. Bowman 2012 and Lubańska 2015). It also avoids the de-differentiation central to arguments such as Hayden's, for instance, which talks of “interactions between the religious communities...not only at the local level, but more widely as well" (Hayden 2016, 85) as though all the members of a nominal religious groupfrom, in Christian cases, laypersons through to priests and patriarchs-can be seen as an agentive unit. There are substantial divergences, and even clashes, between the activities and aims of persons nominally of the same community, and these dissensions are evidence of substantial resistance to movements analogous to what Huntington terms "civilisational rallying" (1993, 39-41). Intra-communal antagonisms, such as those between religious officiants and a diversity of local practitioners, make evident the distinct interest groups involved in pushing, and resisting, rallying. The intervention of state agencies in cases where rallying is effected suggests that power, and state violence, rather than civilisational identification, is the driving force.

At the close of my "Nationalising and Denationalising the Sacred" I argued for more research on intercommunal interactions around holy sites as a means of promulgating "counter-images...allowing for and prompting the imagining of forms of community other than those alienated and isolate forms characteristic of the present" (Bowman 2012a, 219). Citing Walter Benjamin, I suggested that the images of intercommunal conviviality discussed above might be seen as "chips of Messianic time" (Benjamin 1969, 263)-moments of history, buried in the detritus of subsequent and surrounding events, that can be recuperated to show ways in which the present might be seen and experienced differently. Certainly, my investigation into the shaping of discourse by cultural conflict agents and agencies strengthens my sense of the importance of disseminating such studies so as to undermine simplistic arguments about 'clashing civilisations'. 


\section{The Social Contexts of Cohabitation and Antagonism}

When we discuss the social aspects of cohabitation and/or antagonism, it is important to delineate carefully what terrains are being occupied or contested. I would argue that here we are discussing places rather than spaces; places, in this context, are lived-in spaces or, in more academic terms, sites of inhabitance, while space denotes an area, of general or unlimited extent, indifferently providing the physical setting for such places. The Oxford English Dictionary notes that "place" is "a space that can be occupied... a particular spot or area inhabited or frequented by people; a city, a town, a village."13 Spaces are far more easily 'shared' than places, if sharing is the correct term to use when referring to coexisting in contiguous space. When suitably organised, entities can move past and around each other in space without effecting significant contact. Movement in shared places, however, entails negotiation, commensality, and, at times, conflict insofar as persons occupying place not only coexist with each other but are very much aware of the fact of that coexistence.

In Michael Sorkin's fascinating discussion of traffic in Giving Ground: The Politics of Propinquity we see, on the one hand, a modernist mode of organisation that channels persons and vehicles into non-intersecting pathways in order to give priority to unimpeded flow at the expense of relations between entities moving across the same terrain. On the other, Sorkin shows us a more traditional setting in which flow is impeded by repeated intersection and the necessary and mutually aware sharing of place:

Modern city planning is structured around an armature of...conflict avoidance. Elevated highways, pedestrian skyways, subway systems and other movement technologies clarify relations between classes of vehicles for the sake of efficient flow....The result is a city altogether different from the older Indian cities with their indigenous styles of motion....Typically Indian traffic is completely mixed up, a slowmoving mass of cows and pedicabs, motor-rickshaws, trucks and buses, camels and people on foot, the antithesis of "efficient" separation. Motion through this sluggish maelstrom does not proceed so much by absolute right as through a continuing process of local negotiation for the right of passage. (Sorkin 1999, 2)

In the latter case we are shown not only a space occupied by persons and entities but a place in which those inhabiting the terrain are linked together by what he terms "a primal rite of giving ground...the deference to one's neighbour that urban existence

13 Place, n.1. OED Online. March 2013. Oxford University Press (accessed 19 April 2013), see also Casey 1997, Casey 2002, and Massey 2005. 
daily demands" (ibid.). Here, rather than a skein of distinct and mutually disengaged pathways encompassed within a common space, we see a place inhabited by a diversity of persons and objects, shared through processes of mutual recognition and accommodation.

I would like to look further at this issue of "giving ground" in the particular context of shared holy places in the post-Ottoman Eastern Mediterranean ${ }^{14}$ so as to evaluate how such places are shared, what sorts of situations support that sharing, and what sorts of events or developments disrupt it. In a neighbourhood a multitude of different groups of people are tied together into a community by networks that variously engage them as individuals and groups. Shared practices of being in a neighbourhood enable both the recognition of the difference of others and the framing of that difference as something beneficial rather than problematic. Foregrounded here is the issue of whether we can see local communities, and the set of relations that constitute them, as forms of what Bourdieu called habitus. ${ }^{15}$ Bourdieu, in the rather dense terminology of his Logic of Practice, writes that

[t]he conditionings associated with a particular class of conditions of existence produce habitus, systems of durable, transposable dispositions, structured structures predisposed to function as structuring structures, that is, as principles which generate and organize practices and representations that can be objectively adapted to their outcomes without presupposing a conscious aiming at ends or an express mastery of the operations necessary to attain them. (Bourdieu [1980] $1990,53)$

Practices of interaction and negotiation of place experienced through living in a community imprint themselves in individuals as preconscious dispositions to act, and interpret, in the future in accordance with those earlier experiences. A person's dispositions are neither habits nor consciously applied rules but tacit knowledge, often embodied, learned through the "prestigious imitation...[of] actions which have succeeded and which he has seen successfully performed by people in whom he has confidence and who have authority over him" (Mauss [1935] 1979, 101). As Mauss, and Bourdieu after him, make clear, it is this process of internalising social practices (actions, interpretations, self-presentations) that imposes the social on the individual and that,

14 This terrain being that of my ethnographic field research between 1983 and the present.

15 The concept of habitus, itself a Latin translation of the Greek hexis, has a long genealogy stretching back nearly two-and-a-half millennia from Bourdieu's Outline of a Theory of Practice ([1972] 1977) and Logic of Practice ([1980] 1990) via Mauss' Les Techniques du Corps (1935) and Aquinas's Summa Theologica (la2ae, 49-54) to Aristotle's Nichomachean Ethics (1098b33). 
in effect, maps the neighbourhood-and its modes of incorporating and negotiating with internal difference-onto the selves who traverse it. "Giving ground," recognising the right of the other to be in the same place as oneself as well as committing to the rites of negotiating her presence, is a core element of the habitus of neighbourhood.

Two ethnographic studies, one on southern and the other on northern India, exemplify the ways neighbourhoods constituted by nominally distinct religious communities (communities that are elsewhere mutually antagonistic) are able to share place peacefully. The first text, Jackie Assayag's At the Confluence of Two RiversMuslims and Hindus in South India (2004), discusses what might be called a situational syncretism whereby Muslims and Hindus are able to celebrate at each other's religious festivals because, in the course of the communities living together for nearly a millennium, cultural elements that in the past might have been the exclusive properties of distinct communities have become part of an annual cycle of neighbourhood practices and thus, in effect, common property:

The religion of Mohammed insinuated itself very gradually in a Hindu environment already segmented by numerous castes, sects and local traditions. This mixture of discreet elements gave rise to many subtle and complex forms of acculturation caused by alteration, addition, superimposition and innovation, which vary from region to region. So by absorbing elements that were no longer either strictly Hindu or Muslim, but may have been the result of an earlier assimilation, these cultural forms allowed movement between systems of action and representation that seemed to be mutually exclusive. (Assayag 2004, 41)

Anna Bigelow's Sharing the Sacred: Practicing Pluralism in Muslim North India (2010) treats a seemingly more conscious process of intercommunal cohabitation in the town of Malerkotla, located in the Punjab, a far more conflicted region than Assayag's Karnataka. Bigelow notes that the town's cultivated tolerance might be seen as a response to Malerkotlan residents' horror of the sectarian cleansing that afflicted the Punjab during Partition (as well as of the violence of subsequent sectarian riots that have taken place in the region over the past few decades) leading to their recognition that "all religious groups are in some regard vulnerable...[making them] cognizant that their wellbeing depends on their positive relations with others" (Bigelow 2010, 10). However, she demonstrates fulsomely that overt intercommunalism is very much grounded on the town's "practice of everyday pluralism" (ibid., 217) and is a projection of "the vibrant community life in the streets and homes and shrines of a locale" (ibid., 223). In each case the 'cultural property' of one sectarian community is seen by members of adjacent communities as theirs as well, not because they wish to appropriate it 
but because, via a process of living with the 'owners' of the property and engaging with them in their quotidian lives, that property and the practices surrounding it have come to be seen as common. Whereas in some cases, such as those described by Assayag, sharing is unconscious for the most part because the traces of the ownership of significant elements of cultural property have been effaced by time, in others, as in Bigelow's Malerkotla, practices of mutual engagement in religious festivals and shrine worship are conscious moves to affirm community solidarities across sectarian borders. In both instances, however, sharing in religious celebrations and festivities is an extension of the habitus of a shared communal life. ${ }^{16}$

This is not, of course, to say that an identical 'script' of community response is instilled in all the community's members by their participation in a neighbourhood. While the term "disposition" suggests a tendency to interpret situations and act in response to them in certain ways familiar from past engagements with similar events, Bourdieu's work, like Mauss' before it, makes clear that there is "play" in the system of application allowing for accommodating specificities of context, of individuality, and of intention. A disposition is a proclivity rather than an imperative. Part of what accounts for the lability of persons' responses in communities in general and mixed communities in particular is the multitude of identities at play in any individual's experience of everyday life. The concept of "situational identities"17 enables us to recognise that a multitude of identity contexts exists in even the least complex of societies, and that when a community creates complexity to the extent of encompassing multiple ethnic and/or religious identities, the opportunities for a proliferation of identity strategies expands commensurately. At different moments of interaction within the community, different dispositions will be called to the fore. Thus in one instance you might be working with someone as a co-worker or in an employee-employer relation whereas, in another, sometimes even contiguous with the first, you might be called on to represent a family or a religious denomination. Each of these situations will call on distinct dispositions and may in fact call for enunciating those dispositions

16 See also the essays collected in Albera and Couroucli (2009 and 2012) and Bowman (2012).

17 "Situational identity" is a concept generally assumed to have been generated by, but not specifically used in, Erving Goffman's theory of the dramaturgical construction of social identity developed in The Presentation of Self in Everyday Life (1959). Max Gluckman had, however, elaborated the concept of "situational selection" in 1940 as individuals shaping their behaviour, in different social contexts, so as to conform to the values and practices of groups they there associate with: "the shifting membership of groups in different situations is the functioning of the structure, for an individual's membership of a particular group in a particular situation is determined by the motives and values influencing him in that situation. Individuals can thus live coherent lives by situational selection from a medley of contradictory values, ill-assorted beliefs, and varied interests and techniques" (Gluckman [1940] 1958, 26). 
in ways that improvise on previous enactments. What is important to stress is that none of these enacted identities are primary other than in situations-some of which will be elaborated below-in which the primacy of one of those identities is staged as more important than, and either subsuming or obviating, others. Recognition of the situatedness of identity articulations allows us to understand the ways numerous linkages can be made between diverse persons within a community, but also to see that certain events or developments might render previously amenable identities incommensurate and thus conflictual.

Nonetheless, investigation of the character of neighbourhood bonds resonates with Bigelow's $(2010,122)$ examination of Malerkotla's “daily work of community maintenance" and indicates that in most instances communities will seek to perpetuate communal cohesion. The concept of habitus makes clear that the degree to which people are who they are is a consequence of the appropriateness of their learned dispositions to settings the same as, or not unlike, those in which they internalized those dispositions. Radical reworkings of those settings-either through intercommunal conflict and separation or through migration or exile-threaten selfhood. There are, of course, circumstances that bring about the fragmentation of communities, but these often come about through external influences that, through direct action or the indirect impact of rumours or propaganda, create distrust and antagonism between elements of the community (compare again Tone Bringa's film We Are All Neighbours, 1993).

\section{Muslims and Christians in the Monastery of Sveti Bogoroditsa Prechista}

The powers people imagine as working in their world are social powers, conceived of in the image of their own experience of the world. Let me expand on this using an ethnographic encounter I had in Kicevo, Macedonia, in April 2006. I had been researching, with the help of Elizabeta Koneska of the National Museum of Macedonia, Muslim and Orthodox Christian uses of Sveti Bogoroditsa Prechista (the church of the Holy Mother of God Most Innocent) outside of Kicevo, itself a mixed Muslim and Christian town. In the course of examining the context of shared shrine practices, we interviewed the imam of the local Sunni mosque. Trained in the renowned Faculty of Islamic Studies in Sarajevo, he responded to our queries about Muslims attending the nearby Sveti Bogoroditsa monastery by asserting that he had never gone there and

never would. He nonetheless went on to explain that he would advise members of his congregation to go to the monastery for help with particular problems because 
the world of demons, like our world, is made up of Christians and Muslims. When someone is afflicted by a Muslim demon I can deal with the problem, but when someone is troubled by a Christian demon there is nothing I can do, so I send them to the church. (Interview, Kicevo, 30 April 2006)

What is of interest here, besides the concept of a mirror world of demons that replicates the demography of the lived world, is that-in this local context-the imam seems to see no incommensurability between this vision of the interaction of the demonic and the human worlds and that of a more Orthodox Sunni theology with its considerably stricter definition of domains, borders, and pollutions. ${ }^{18}$ Here, relations between the human and the demonic world are analogous to those occurring in the quotidian world of social interaction, and rites and obeisance made in the human world engage an economy of reciprocity with the demonic.

Just as the demonic world mirrors the intermixing of Muslim and Christian while maintaining the difference between the two, so, too, do movements within the ritual space of the church maintain that differentiation, even as Muslims "tap into" Christian rituals to ward off Christian demons. Sharing the space of the Sveti Bogoroditsa monastery's chapel does not entail a syncretic blending of identities, just as interacting on the streets and in the markets of Kicevo and its satellite villages does not effect an effacement of sectarian identities (compare Lockwood 1975, especially 195-211). Muslims within the walls of the church seem, on initial observation, to go through the same procedures of reverencing the saints and the sites of power as do Christians: they circulate through the church, they light candles in front of the icons (particularly those of the iconostasis, before which they lay gifts of clothing, towels, and sometimes money), and they proceed to the rear left of the church where, like the Christians, they pass a string of cross-inscribed beads over their bodies three times before crawling three times through a passageway beneath a pair of healing icons toward a well from which, in leaving, they take water to splash on their faces and carry home in bottles for healing (see Bowman 2010, 206-209, for a more detailed description). Closer observation reveals that this apparent mimicry is subtly but significantly differentiated. Muslims, holding back from Christian groups, introduce small but important differences of deportment. They do not cross themselves; they bow their heads before but do not kiss the icons; and, in praying, they silently mouth Muslim prayers while holding their hands close to their chests in front of them with their palms up. Muslims here 'work' an environment they know through the social world they share with their Christian neighbours and, in so doing, both engage in ritual acts that they have learned are

18 As I will show below, when the world of religious orthodoxy impinges upon local practices, it disrupts this intercommunalism, asserting property and propriety issues at the expense of sharing. 
efficacious from their neighbours (and their imam) and render appropriate obeisance to the powers resident in the place (the Virgin Mary, the saints, the Mother Superior, and the nuns). At the same time they refuse to violate their own identities by sacrilegiously adopting the signifiers of Christians as though they were their own. Here, in a religious setting, we have an interaction analogous to what Sorkin describes in the dense streets of Indian cities- "the continuing process of local negotiation for the right of passage". (Sorkin 1999, 2)

\section{Property and Propriety in Jerusalem's Church of the Holy Sepulchre}

The 'sharing' described above-a sharing extending into religious places the same modes of intercommunal mixing one sees in the everyday interactions of neighbours in the streets and workplaces of the region-differs substantially from the types of interactions one sees between strangers in sites they commonly revere, but not 'in common'. I will try to resolve this seeming contradiction between 'commonly revering' but not 'in common' through again referring to the "rigid designator" discussed by Kripke and Žižek (see also Vološinov [1929] 1973, 79-80). Generally, in a world of shared experience, "rigid designators" suffice to indicate objects and experiences common to those sharing that world, subsuming idiosyncrasies of personal experience or contextual application. However, where quotidian experience is not shared, identical signifiers may conjure up very different signifieds for the communities using them, and the differences may, in fact, prove to be incommensurabilities. In earlier examinations of the politics of Palestinian identity before and after Oslo (Bowman 1988, 1994), I wrote of the different ways the name "Palestine" signified both a future homeland and a reunified people to communities in different locales of exile, both outside and inside the borders of historic Palestine. So long as those populations remained isolated from each other, these disparities of understanding remained relatively unproblematic, but once Oslo effected a regathering of the Palestinians from the various sites of their dispersion serious conflicts erupted between groups over what Palestine should be, what Palestinians should be like, and who was, in fact, even truly Palestinian.

Something very similar happens at holy places with constituencies that gather from dispersed locales. Rather than neighbours sharing a sacred place, here we are talking of strangers coming together in the same space. The Holy Sepulchre in Jerusalem, known to Orthodox Christians as the Anastasis, lies at the centre of an extended web 
of narratives dealing with the death and resurrection of Jesus. ${ }^{19}$ When I carried out field research on Jerusalem pilgrimage in the early 1980s, the Holy Sepulchre, like other sites throughout the 'holy city' of Jerusalem, was visited by pilgrims from twenty-seven distinct Christian denominations (these, for the most part, further divided into distinct regional, national, and linguistic communities) as well as by a multitude of tourists, many from Christian backgrounds, but also many non-Christians. Five sects had places within the church-the Greek Orthodox, Catholics, and Armenians occupying the most territory, with the Coptic and Syrian Orthodox holding tiny chapels-while a sixth, the Ethiopians, held two external chapels and a rooftop. Despite this sectarian topography, the church was swept daily with pilgrims and tourists, the crowds flowing indiscriminately through the corridors and chapels. ${ }^{20}$ Such heterodoxy within a limited space could give rise to 'traffic problems' (pushing, expressions of hostility, and occasionally fights, usually between individuals not travelling in organised groups) but, for the most part, conflicts were avoided by what appeared to be spontaneous traffic management. This took place not through "local negotiation" but because groups moving through the church effectively 'enclaved' themselves into mobile units flowing past and alongside each other without either engagement or significant mutual recognition (see Bowman $2011,376-77)$. These groups, often made up of people coming from the same locale or brought together prior to the visit by an institution or a leader, constituted 'ingroups' able not only to insulate themselves from others but also, under the authority of spiritual or secular guides associated with the respective groups, to ensure that their perceptions of the sites and events they encountered confirmed and built upon their expectations. Such a mode of engaging with holy sites protected the integrity of the connection between rigid designators and the experiences they signified, while preventing the cognitive dissonance of others' readings of those shared designators from disrupting that alignment. ${ }^{21}$ While individuals within these groups shared with each other an experience of place, they simultaneously related to members of other groups like bodies in space, moving past and around them without effecting significant contact. Thus, while this site might nominally be termed a "shared site," the character of this interaction throws doubt on the applicability of the phrase "shared."

19 Despite the difference in name, the "place' of the crucifixion, tomb ("sepulchre"), and resurrection ("anastasis") of Jesus is established at the heart of New Testament biblical narratives, so that this nominal place can function as a rigid designator, even when ideas of its actual location can differ by several hundred meters (including the Anglican Garden Tomb, which lies outside the walls of the Old City).

20 The Greek Orthodox Katholicon was, however, normally closed to all but the Greek Orthodox.

21 These strategies were carried out throughout Holy Land pilgrimages and, one suspects, across other forms of organised travel-see Schmidt 1979. 
The relations described above rarely become conflictual because while those involved share the same space they rarely share the same place. For the majority of pilgrims travelling in mobile enclaves, the experience of holy places provides an intimate confirmation of the 'reality' of those sites and of the pilgrims' personal relations to that 'reality'; seeing the 'real' place, without being forced to acknowledge the dissonance of others' interpretations of its reality, provides a sense of spiritual ownership that visitors take back to their places of origin. ${ }^{22}$ "Strangers" do not need to literally own the place because they do not live there. For them it is enough to experience the place and possess the knowledge of its reality.

Relation to place is very different for the monks and priests who move through and live in the immediate vicinity of the church. Here we see institutionally shaped situations which resonate with the scenarios sketched, respectively, by Hassner and Hayden. These religious officiants see themselves as 'owning' the holy sites in a much more literal way, and their conception of property-and of propriety (an etymologically related term) - can but be conflictual when others who are not of the same community have similar claims on the sites and different conceptions of the modes of deportment proper to them. The Franciscan, Armenian, and Greek Orthodox brotherhoods that care for their respective chapels within the building ${ }^{23}$ are brought into daily, often conflictual, contact with others whose sense of the site's significance, the legitimacy of its possession, and the appropriateness of ritual activities carried out therein differ on numerous points. Although these men cohabit in the Holy Sepulchre and its neighbourhood, they do not share locale and dispositions in the ways set out earlier. Jeff Halper describes the monasteries of the Christian Quarter in the late Ottoman period as each enclosing radically different lifeworlds, redolent of the nations of the monks' origins (Greece, France, Armenia) rather than of Jerusalem (Halper 1984). In many ways, at least in terms of self-sufficiency and ideological closure, the situations in the monasteries have not changed much. These insulated habitus produce literal neighbours who are, in effect, strangers. Unlike pilgrims, who move past each other in the holy sites as migratory strangers, these hierophants are continuously forced to deal, in "their" holy places, with the presence of others who see those places as their own. For the monks and priests the holy sites in the 'shared' space of the Anastasis or Holy

22 Those whose experiences do not live up to their expectations, or in fact seem to refute them, may be impelled to deny that the sites are the "real" sites (either because the 'real' sites are elsewhere or because they have been effaced by time) or may be forced to question their previous assumptions and beliefs.

23 The Coptic, Syrian, and Ethiopian Orthodox, who possess chapels because of historic precedent, are small communities with little political or economic power, and their presence in the church is rarely challenged by the dominant religious communities (although they fight among themselves over the territories they do control; see Bowman 2011, 389-391). 
Sepulchre are organically connected to the 'pure' cultural spaces of the monasteries, and the presence of others in 'their' spaces, much less the attempt of those others to claim the spaces as 'their own', is anathema. Whereas in the above-cited situations of urban Indian traffic and Macedonian shrine sharing mutual investment in 'common ground' gives rise to generally amenable and decorous ritual processes of negotiation over co-presence, in the Holy Sepulchre quotidian encounters between representatives of the respective churches are only prevented from breaking into open violence by the regimen of the Status Quo, a system of spatial and temporal regulations initially imposed by the Ottoman state and currently maintained through fear of the open intercommunal warfare and state side-taking that its rejection would provoke. ${ }^{24}$

At the core of this conflict is not a simple issue of property ownership; actual property can-as the tenets of the Status Quo themselves assert-be shared, albeit through complex ritual regimes. Instead we are looking at issues more closely tied to propriety and, through that, to identity. Monks and priests associated with the Holy Sepulchre are able, when outside of domains demarcated as sacred, to relate to secular locals and even to members of other fraternities in non-conflictual-sometimes even amenable-ways (Tsourous 2017, 251-287). In contexts where religious identities are foregrounded, however, particularly in the choreographies of movements through the spaces of holy sites, they become representatives of their particular religious community or "defenders of the holy places," as members of the Greek Orthodox Brotherhood of the Holy Sepulchre called themselves in the wake of a fight with Armenian monks over contested space in Bethlehem's Church of the Nativity (fieldnotes, 31 December 1984). In these contexts, they and the places they 'protect' manifest the truth value of their church and its theology; their presence in the places and the rituals they carry out there are seen to 'suture' their dogma and their orthopraxy with Christian revelation. The presence of others carrying out their apostate rituals and asserting their authority in those places constitutes what Laclau and Mouffe term an "antagonism" (Laclau and Mouffe 1985, 93-148)-literally a radical denial of their own assertions of identity as the sole vehicles of the true church. ${ }^{25}$

It is in this context that property, and the propriety of liturgical demeanour therein, becomes an issue of overarching concern. Concern with overcoming the antagonism presented by the presence of other belief communities is what motivates

24 See Fisher-Ilan 2004 for one of many examples. Cohen 2008 and Bowman 2011, 2014 address different interpretations of how and why the Status Quo is maintained.

25 "In the case of antagonism...the presence of the 'Other' prevents me from being totally myself. ...(it is because a peasant cannot be a peasant that an antagonism exists with the landowner who is expelling him from his land). Insofar as there is antagonism, I cannot be a full presence for myself" (Laclau and Mouffe 1985, 125). 
the insistence of the various religious communities that they 'own' holy places and drives the demands of religious authorities worldwide that shrines and holy places be purged of heterodox practices and persons. The politics of the "rigid designator" is the insistence that there is but one signified for the signifier. While this may appear to take the shape of straightforward demands for sole possession and inhabitance of a holy place, beneath that demand is the assertion of the truth-value of a core identity and the insistence that no other representation can lay claim to the place where that identity manifests and celebrates itself. As a Greek monk told Nikos Kazantzakis when he visited the Anastasis in 1927:

This entire church belongs to us, the Orthodox. All the sacred shrines are ours. ...[W]e're going to throw the Armenians out....Whatever the Latins tell you is a lie. All their shrines are fakes. I hope to God the day comes when we can throw them out." (Kazantzakis 1973, 153)

\section{Sveti Nikola/Hadir Bābā: Simultaneity of Place}

The concept of 'property' functions in various ways in sites we refer to as 'shared'. In the case of Sveti Bogoroditsa Prechista, Muslims attending the monastery's church do not in any way dispute the Macedonian Orthodox Church's ownership of the site, visiting and using it with due deference to the nuns who live there. The Mother Superior and the majority of the nuns are in no way threatened by the presence of Muslims in the church, appreciating their generosity ("they give more than the Christians") and recognizing coexistence within the site as a welcome consequence of the long-term good relations of Muslims and Christians in the nearby town and surrounding countryside ${ }^{26}$ (see Bowman 2010, 209-212).

In another Macedonian site I have written on, Sveti Nikola, in Makedonski Brod, Sufi and Sunni Muslims praying in the church recognise the authority of the Orthodox caretakers, yet simultaneously associate the edifice and the tomb within it with the Bektashi saint Hadir Bābā. Relations between the Christian visitors from the town and the Muslim visitors from neighbouring settlements are cordial, and lubricated-as at Sveti Bogoroditsa-by the generosity of Muslims, whose copious gifts are auctioned off to support the town's main church. Intriguingly, in the case of Sveti Nikola/Hadir Bābā, mutual commitment by both communities to the continued sharing of the site

26 Although one university-trained novice, recently relocated to the monastery from Skopje, expressed hostility toward Muslim visitors, refusing to give them holy water and claiming they were planning to "steal" the church (Bowman 2010, 209). 
is manifest in the simultaneous display of Sufi and Christian iconography within the church although, as I describe in my study of the site, perceived imbalances of display are able to give rise to aggrievement and potential hostility (Bowman 2010, 203-206).

In both instances, as at the shrine of Haider Shaikh in Malerkotla described by Anna Bigelow, the local communities as well as the officiants at the religious sites commit themselves to maintaining, within the shrines, forms of intercommunal cooperation cognate with those taking place beyond their perimeters. Changes in that wider context of social relations, resulting in a breakdown of conviviality, can fracture that commitment, making way for one community to attempt to force the other from the shrine; such an expulsion would mirror that affected in the surrounding social world. In other instances, religious authorities, often backed by individuals of influence over local members of one or the other local religious community, may exploit frictions or fissures in the local community to push for the 'purification' of a shrine. Even in such instances, however, the perceived sanctity of a site may be retained by the general population so that not only members of the religious and ethnic communities banished from the site might return, covertly and sometimes overtly, but also, as relatively amicable intercommunal relations in the surrounding locale are re-established, the site may again begin to be shared (see Bowman 2012, 215-17).

Shrines such as the Anastasis or Holy Sepulchre are very different from those such as Sveti Nikola/Hadir Bābā and Sveti Bogoroditsa Prechista insofar as, rather than being perceived as property of the local community (in both the sense of belonging to the local milieu and being characteristic of that social formation), they are presented as standing outside of their immediate context, belonging instead to ideologically constituted communities that may originate, and even reside, at a substantial physical and cultural distance from their literal site. For pilgrims visiting such sites from afar, the holy places 'belong' to them in a spiritual or devotional sense. They ideologically imagine the place as a spiritual possession that, once witnessed, can be 'taken home' for meditation and validation, but their desire to literally possess the place rarely extends further than their wish to collect relics (oil, candles, carved olive wood crosses) that metonymically connect them with the place. For resident clergy, however, such holy places not only 'belong' to their sects in a spiritual sense but must literally belong to their churches, since possession of the site both confirms their core identities as guardians of the holy places and authorises and amplifies the sanctity of the site through their provision of appropriate liturgical practices (and their blockage of heterodox practices). Here, the presence of others not only presents an integral challenge to their identities but also desecrates the sanctity of that central site (see Hassner 2009). "Tolerance" is anything but toleration in this context as it is in effect no more than enforced cohabitation. 


\section{Strangers and Neighbours}

The distinction between 'space' and 'place' set out earlier is key to understanding the emergence of antagonism in shared sites. Space, as an encompassing container, is able to hold a number of entities without their having any relation aside from that of contiguity. Place, as a site of inhabitance, can contain differentiated bodies, but these, by sharing place, enter into relations with each other. Thus, on the one hand, pilgrim groups, converging on the same holy sites from different places of origin, are able to flow around and past each other, each pursuing their own realisations of their own envisionings of the significance of the sites they temporarily occupy. The 'place' each group inhabits is effectively rendered discontinuous with the 'places' of others, and interaction is kept minimal and impersonal. On the other hand, neighbours of different sectarian affiliations can meet in local holy places, engaging with each other through media of negotiation and mutual recognition analogous to those they use in their everyday interactions outside of holy ground. Here, each group simultaneously occupies the same place and must engage modes of mutual accommodation, rendering this coexistence as non-conflictual and as mutually beneficial as possible. In the instance of the Holy Sepulchre or Anastasis, a situation not unlike others worldwide in which religious powers work to present a site as a pure signifier of an exclusive identity that must be defended from the pollution of other forms of worship, ${ }^{27}$ two or more communities attempt to construct, and inhabit (literally and ritually), exclusive places at the same time in coterminous spaces. Such cohabitation is, in terms of the communities' respective discourses, an impossibility, and thus the presence of the other presents a literal antagonism that must either be overcome through expulsion or succumbed to by withdrawal; the structure of this particular relation is that of both Hassner's and Hayden's conceptions of the impossibility of sharing. The 'stand-off' that is the current status quo effected by the Status Quo is an ideological impossibility, and the Holy Sepulchre/Anastasis will remain a flashpoint, surrounded by the tinder of cadres of ideologically motivated monks, until either a discursive shift in the respective theologies replaces antagonism with fraternity or one group successfully expropriates and 'cleanses' the site.

In the post-Ottoman sphere, where conceptions of 'nationalist' identity increasingly impose themselves on domains where 'national' identities had served as markers of

27 A salient example is the 1992 destruction by Hindu activists of the Babri Mosque at Ayodhya in order to clear the site for the construction of the Sri Ram Janam Bhumi Temple commemorating the birthplace of Lord Rama (an avatar of Vishnu). 
nominal difference within mixed communities, ${ }^{28}$ places that had been shared-whether secular or sacred-are transformed into the exclusive properties of ethno-national groupings. Sharing, or even mixing, is there rendered contentious, and local events in which individuals with different allegiances clash come to be read more widely as indubitable signifiers of irresolvable antagonisms. Once such a discursive shift has taken place, and shared sites have been transformed into terrains on which struggles for possession take place, it becomes increasingly impossible to imagine contemporary cohabitation and sharing, and the image of coexistence fades into a utopian fantasy of a distant 'Ottoman' past (see Kamel 2019). Such a process of dissolution, to which Susan Woodward refers with reference to Former Yugoslavia as the "Balkan Tragedy" (Woodward 1995), appears to be the course onto which the clash of civilisations discourse is routing us, and at its terminus we, too, may sadly look back on the project of secular enlightenment as no more than a utopian fantasy.

As Benjamin knew, one cannot be so intellectually naïve as to believe that works such as his own and those cited in support of intercommunalism can change history; history-intellectual and political-is shaped by discourse, and discursive power relies on far more than words. Nonetheless, good scholarship can put into question the 'common sense' produced by those behind identitarian and clash of civilisations discourses, and offer alternative understandings resisting that ideology and the politics that inform it. Showing that difference can cohabit is important, but demonstrating how it does so, the socio-historical field in which it occurs, and what works against cohabitation, grounds and empowers a counter-discourse.

\section{Bibliography}

Albera, Dionigi, and Maria Couroucli, eds. 2009. Religions traversées; Lieux saints partagés entre chrétiens, musulmans et juifs en Mediterranée. Arles: Actes Sud.

- - - eds. 2012. Sharing Sacred Spaces in the Mediterranean: Christians, Muslims, and Jews at Shrines and Sanctuaries. Bloomington: Indiana University Press.

Albera, Dionigi, Manuel Penicaud and Isabelle Marquette, eds. 2015. Lieux Saints Partagés. Catalogue of MuCEM exhibition. Marseilles/Arles: MuCEM/Acts Sud.

Assayag, Jackie. 2004. At the Confluence of Two Rivers: Muslims and Hindus in South India. New Delhi: Manohar.

28 See Bowman 2015 as well as my discussion of the Titoist treatment of 'national' versus 'nationalist' identities in Bowman (2003, 229-30). 
Badiou, Alain. 200. The Century, translated by Alberto Toscano. Cambridge: Polity Press.

Barkan, Elazar, and Karen Barkey. 2014. Choreographies of Shared Sacred Sites. Religion, Politics and Conflict Resolution. New York: Columbia University Press.

Barkey, Karen. 2008. Empire of Difference. The Ottomans in Comparative Perspective. Cambridge: Cambridge University Press.

Baskar, Bojan. 2012. "Komšiluk and Taking Care of the Neighbor's Shrine in BosniaHerzegovina." In Albera and Couroucli 2012, 51-68.

Bastin, Rohan. 2012. "Saints, Sites and Religious Accommodation in Sri Lanka." In Bowman 2012c, 97-117.

Benjamin, Walter. (1950) 1969. "Theses on the Philosophy of History." In Illuminations, edited by Hannah Arendt, translated by Harry Zohn, 253-264. New York: Schocken.

Bigelow, Anna. 2003. "Places of Peace, Places of Power." Presentation at the Center for South Asian Studies. University of Virginia, Charlottesville, VA, January 31, 2003.

-_- 2010. Sharing the Sacred: Practicing Pluralism in Muslim North India. Oxford: Oxford University Press.

-_-. 2012. "Everybody's Baba: Making Space for the Other." In Bowman 2012c, 2543.

Bonney, Richard. 2008. False Prophets: The 'Clash of Civilizations' and the Global War on Terror. Oxford: Peter Lang.

Bourdieu, Pierre. (1972) 1977. Outline of a Theory of Practice, translated by Richard Nice. Cambridge: Cambridge University Press.

-_-. (1980) 1990. The Logic of Practice, translated by Richard Nice. London: Polity Press.

Bowman, Glenn. 1988. "Tales of the Lost Land: Palestinian Identity and the Formation of Nationalist Consciousness." New Formations 4: 31-52.

- - 1993 "Nationalizing the sacred: shrines and shifting identities in the Israelioccupied territories." Man: The Journal of the Royal Anthropological Institute XXVIII (3): 431-60.

- - . 2003. "Constitutive Violence and the Nationalist Imaginary: Antagonism and Defensive Solidarity in 'Palestine' and 'Former Yugoslavia'." Social Anthropology XI (3): 319-340.

- - . 2010. "Orthodox-Muslim Interactions at 'Mixed Shrines' in Macedonia." In Eastern Christians in Anthropological Perspective, edited by C. Hann and H. Goltz, 195-219. Berkeley: University of California Press. 
- - . 2011. “'In Dubious Battle on the Plains of Heav'n': The Politics of Possession in Jerusalem's Holy Sepulchre." History and Anthropology XXII: 371-99.

- - . 2012a. "Nationalizing and Denationalizing the Sacred: Shrines and Shifting Identities in the Israeli-Occupied Territories." In Sacred Space in Israel and Palestine: Religion and Politics, edited by Yitzhak Reiter, Marshall Breger and Leonard Hammer, 195-227. London and New York: Routledge.

- - . 2012b. "Identification and Identity Formations around Shared Shrines in West Bank Palestine and Western Macedonia." In Albera and Couroucli 2012, 11-30.

- - , ed. 2012c. Sharing the Sacra. The Politics and Pragmatics of Intercommunal Relations around Holy Place. New York and Oxford: Berghahn.

- - . 2013a. "Popular Palestinian Practices around Holy Places and Those Who Oppose Them: An Historical Introduction." Religion Compass 7 (3): 69-78.

-_-. 2013b. "A Weeping on the Road to Bethlehem: Contestation over the Uses of Rachel's Tomb." Religion Compass 7 (3): 79-92.

- - 2013c. "Review of Anna Bigelow, Sharing the Sacred: Practicing Pluralism in Muslim North India." Comparative Studies in Society and History 55: 507-509.

- - . 2014. "The Politics of Ownership: State, Governance and the Status Quo in the Anastasis (Holy Sepulchre)." In Barkan and Barkey 2014, 202-240.

- - . 2016. "Grounds for Sharing-Occasions for Conflict: An Inquiry into the Social Foundations of Cohabitation and Antagonism." In Post-Ottoman Coexistence: Sharing Space in the Shadow of Conflict, edited by Rebecca Bryant, 258-275. New York and Oxford: Berghahn.

Bringa, Tone (anthropological advisor). 1993. "We Are All Neighbours.". Disappearing World. Directed by Debbie Christie. Granada Television.

Brubaker, Rogers. 2002 "Ethnicity Without Groups." Archives Européenes de Sociologie: European Journal of Sociology XLIII (2): 163-189.

-_- 2004. Ethnicity Without Groups. Cambridge: Harvard University Press.

Casey, Edward S. 1997. The Fate of Place: A Philosophical History. Berkeley: University of California Press.

-_- 2002. Representing Place: Landscape Painting and Maps. Minneapolis: University of Minnesota Press.

Cohen, Raymond. 2008. Saving the Holy Sepulchre: How Rival Christians Came Together to Rescue Their Holiest Shrine. New York: Oxford University Press.

Cormack, Margaret, ed. 2013. Muslims and Others in Sacred Space. Oxford: Oxford University Press.

Couroucli, Maria. 2009. "Saint Georges l'Anatolien, maître des frontièeres." In Albera and Couroucli 2009, 175-208 
- - . 2010. "Empire Dust: The Web of Relations in Saint George's Festival on Princes Island in Istanbul." In Eastern Christians in Anthropological Perspective, edited by Chris Hann and Hermann Goltz, 220-239. Berkeley: University of California Press.

Cuffel, Alexandra. 2003. “'Henceforth All Generations Will Call Me Blessed': Medieval Christian Tales of Non-Christian Marian Veneration." Mediterranean Studies XII, 37-59.

Driessen, Henk 2012. "A Jewish Muslim Shrine in North Morocco: Echoes of an Ambiguous Past." In Albera and Couroucli 2012, 141-147.

Fisher-Ilan, Allyn. 2004. "Dozens Hurt as Clerics Clash in Jerusalem Church." In AlertNet: Reuters Foundation.

Fowden, Elizabeth Key. 1999. The Barbarian Plain: Saint Sergius between Rome and Iran. (The Transformation of the Classical Heritage XXVIII). Berkeley: University of California Press.

-_-. 2002. "Sharing Holy Places". Common Knowledge VIII (1): 124-146.

Gilsenan, Michael. 1982. Recognizing Islam. London: Croom Helm.

Gluckman, Max. (1940) 1958. The Analysis of a Social Situation in Modern Zululand. Rhodes Livingston Paper No. 28). Manchester: Manchester University Press.

Goffman, Erving. 1959. The Presentation of Self in Everyday Life. Garden City, NJ: Doubleday Anchor.

Halper, Jeff. 1984. "On the Way: The Transition of Jerusalem from a Ritual to a Colonial City (1800-1917)." Urban Anthropology XIII: 1-32.

Hassner, Ron. 2009. War on Sacred Grounds. Ithaca: Cornell University Press.

- - . 2010. "The Pessimist's Guide to Religious Coexistence." In Holy Places in the Israeli-Palestinian Conflict: Confrontation and Co-existence, edited by Yitzhak Reiter, Marshall Breger and Leonard Hammer, 145-157. London: Routledge.

Hayden, Robert. 2002. "Antagonistic Tolerance: Competitive Sharing of Religious Sites in South Asia and the Balkans." Current Anthropology 43 (2): 205-231.

- - . 2000. "Muslims as 'Others' in Serbian and Croatian Political Discourse." In Neighbors at War: Anthropological Perspectives on Yugoslav Ethnicity, Culture and History, edited by Joel Halpern and David Kideckel, 116-124. Philadelphia: University of Pennsylvania Press.

- - . 2015. "Intersecting Religioscapes in Post-Ottoman Spaces: Trajectories of Change, Competition and Sharing of Religious Spaces." In Shared Spaces and their Dissolution: Practices of Coexistence in Cyprus and Elsewhere, edited by Rebecca Bryant, 59-85. New York and Oxford: Berghahn. 
Hayden, Robert, Tuğba Tanyeri-Erdemir, Timothy D. Walker, Aykan Erdemir, Devika Rangachari, Manuel Aguilar-Moreno, Enrique López-Hurtado, and Milica BakićHayden. 2016. Antagonistic Tolerance: Competitive Sharing of Religious Sites and Spaces. London and New York: Routledge.

Henig, David. 2012 “'Knocking on my neighbour's door': On metamorphoses of sociality in rural Bosnia." Critique of Anthropology 32 (1): 3-19.

Huntington, Samuel. 1993 “The Clash of Civilizations?" Foreign Affairs LXXII (3): 22-49.

- - - 1996. The Clash of Civilizations and the Remaking of World Order. New York: Simon and Schuster.

Kamel, Lorenzo. 2019. The Middle East from Empire to Sealed Identities. Edinburgh: Edinburgh University Press.

Kaplan, Robert 1993. Balkan Ghosts: A Journey through History. New York: St. Martin's Press.

Kazantzakis, Nikos. 1973. Journeying: Travels in Italy, Egypt, Sinai, Jerusalem and Cyprus, translated by Themi Vasils and Theodora Vasils. Boston: Little, Brown and Company.

Koneska, Elizabeta. 2013. "Shared Shrines in Macedonia". In Forum Folkloristika 2. https://eefc.org/post-folklorista/shared-shrines-in-macedonia/.

Kripke, Saul. 1980. Naming and Necessity. Oxford: Blackwell.

Laclau, Ernesto, and Chantal Mouffe. 1985. Hegemony and Socialist Strategy: Towards a Radical Democratic Politics, translated by Winston Moore and Paul Cammack. London: Verso.

Lewis, Bernard. 1990. "The Roots of Muslim Rage." The Atlantic Monthly CCLXVI (3): 47-60.

Lockwood, William. 1975. European Moslems: Economy and Ethnicity in Western Bosnia. (Studies in Anthropology). New York: Academic Press.

Lubańska, Magdalena. 2013 “Muslim Pilgrims at the Orthodox Christian Monastery in Hadzhidimovo: Studies on Religious Anti-syncretism in the Western Rhodopes, Bulgaria." Anthropological Journal of European Cultures 22 (2): 91-110.

- - - 2015. Muslims and Christians in the Bulgarian Rhodopes. Studies on Religious (Anti)Syncretism. Berlin: De Gruyter.

Massey, Doreen. 2005. For Space. London: Sage Publications.

Mauss, Marcel. 1935. "Les Techniques du corps." Journal de psychologie normale et pathologique XXXII: 271-93.

_-_. (1935) 1979. "Body Techniques." In Sociology and Psychology: Essays, trans. Ben Brewster, 95-123. London: Routledge and Kegan Paul.

Mayer, Jane. 2016a. Dark Money. London: Scribe. 
- - . 2016b. "How Right-Wing Billionaires Infiltrated Higher Education." In The Chronicle of Higher Education. February 12, 2016. http://www.chronicle.com/ article/How-Right-Wing-Billionaires-/235286.

Medvetz, Thomas. 2012. Think Tanks in America. Chicago: University of Chicago Press. Meri, Josef W. 1999. "Aspects of Baraka (Blessings) and Ritual Devotion Among Medieval Muslims and Jews." Medieval Encounters 5: 46-69.

- - . 2002. The Cult of Saints Among Muslims and Jews in Medieval Syria. (Oxford Oriental Monographs). Oxford: Oxford University Press.

Ratner, Lizzy. 2005. "Olin Foundation, Right Wing Tank, Snuffing Itself ." In The Observer. May 9, 2005 http://observer.com/2005/05/olin-foundation-rightwingtank-snuffing-itself/.

Schmidt, Catherine. 1979. "The Guided Tour: Insulated Adventure." Urban Life 7: 44168.

Short, Thomas. 2007. Peirce's Theory of Signs. Cambridge: Cambridge University Press.

Sorabji, Cornelia. 2008. "Bosnian neighbourhoods revisited: tolerance, commitment and komšiluk in Sarajevo." In On the Margins of Religion, edited by Francis Pine and Joao Pina-Cabral, 97-112. Oxford: Berghahn.

Sorkin, Michael. 1999. "Introduction: Traffic in Democracy." In Giving Ground: The Politics of Propinquity, edited by Joan Copjec and Michael Sorkin, 1-15. London: Verso.

Spring, Joel. 2010. Political Agendas for Education. (Sociocultural, Politics and Historical Studies in Education). New York and Abingdon: Routledge.

Tsourous, Georgios. 2017. "Boundaries and Borders: Choreographies among the Rum Orthodox of Old City Jerusalem." PhD diss., University of Kent.

Valtchinova, Galia. 2012. "The Mount of a Cross. Sharing and Contesting Barriers on a Balkan Pilgrimage Site." In Albera and Coucoucli 2012, 69-93.

Vološinov, Valentin N. (1929) 1973. Marxism and the Philosophy of Language, trans. Ladislav Matejka and I. R. Titunik. Cambridge, Massachusetts: Harvard University Press.

Woodward, Susan. 1995. Balkan Tragedy: Chaos and Dissolution After the Cold War. Washington, D.C.: The Brookings Institute

Wright, Robin. 1992. "Islam, Democracy and the West." Foreign Affairs 71 (3): 131-145. Žižek, Slavoj. 1989. The Sublime Object of Ideology. (Phronesis). London: Verso. 